\title{
JOINT MESSAGE OF THE LEAGUE OF RED CROSS AND RED CRESCENT SOCIETIES AND THE INTERNATIONAL COMMITTEE OF THE RED CROSS*
}

This World Red Cross and Red Crescent Day, governments around the world have been making a Humanitarian Gesture as a "birthday present" to our Movement in this, its 125 th year.

These Gestures give hope and dignity to persons who are deprived, forgotten and in despair; people whose condition could not be improved without an act of exceptional benevolence.

Today the Geneva Conventions are the world's most widely accepted treaties. By becoming party to them, states everywhere have shown their commitment to humanity and to the protection of human life.

The Humanitarian Gestures made by governments today are a further link in this chain of international solidarity. They are a very special way of marking 125 years of solidarity with the victims of conflicts and natural or man-made disasters, 125 years of fidelity to the fundamental principles of a Movement which has to date rescued millions of people from death, oblivion and catastrophe.

In the words of our founder Henry Dunant, today's Humanitarian Gestures are another step in the process whereby the governments of the world are "won over to the cause of universal brotherhood".

Even in the most desperately inhuman and violent situations, one humanitarian gesture can be the spark that kindles a gleam of hope for a better way of life and eventually ignites the flame of peace.

When you reach out with open arms in a situation otherwise dominated by the clenched first, you can, in the midst of violence and disaster, foster trust and brotherhood. This is because such a gesture is inspired not by fear or domination, but by respect for people as human beings. It is proof that, in the face of suffering, it is possible to cease being enemies and to work together for the common good.

* This message has been recorded by:

Mr. Cornelio Sommaruga, President of the International Committee of the Red Cross (speaking in French, German and Italian);

Dr. Mario Villarroel Lander, President of the League of Red Cross and Red Crescent Societies (speaking in Spanish);

Mr. Pär Stenbäck, Secretary General of the League of Red Cross and Red Crescent Societies (speaking in English);

Dr. Ahmad Abu-Goura, Chairman of the Standing Commission of the Red Cross and Red Crescent (speaking in Arabic). 
Today 250 million members of the Red Cross and Red Crescent are ready to accomplish such gestures every day, in order to save the lives and relieve the suffering of those who become the victims of natural disasters or man-made catastrophes.

Our Movement continues to base its conviction and determination on the human capacity to be moved by the suffering of others and to refuse to see that suffering as unavoidable.*

\section{HUMANITARIAN GESTURE}

\section{Reference paper}

Today is World Red Cross and Red Crescent Day. For the entire Movement. For the millions of members and volunteers-including 90 million young people! —of the 148 National Societies. For the staff and delegates of the ICRC and the League.

This year there are three reasons to celebrate 8 May. Two birthdays and "birthday gifts", in the service of one cause-"protecting human life".

First, today is the anniversary of the birth of our Movement's founder, Henry Dunant. And with him, the birth of a vision, an endeavour and an organization.

Secondly, 1989 World Day is the year of 125 th anniversary of the initial Geneva Convention of 1864 and the 40th anniversary of the 1949 Geneva Conventions.

And finally, the third reason. In response to requests from their National Societies, a number of Governments have today announced a Humanitarian Gesture to mark the 125th anniversary of the Movement and to illustrate-better than any speech - the spirit which guides Red Cross and Red Crescent action.

1. In 1859 , Henry Dunant was horrified to see that thousands of soldiers no longer able to fight were left to die of their wounds, of thirst and hunger, on the battlefield of Solferino.

How can we today not fail to be similarly horrified by the arbitrary, pointless and intolerable acts of violence which are committed throughout the world against so many people? How can we not want these cruel acts-a shame to all humanity-to stop?

How can we remain impassive and not do everything possible to protect the life and ease the suffering of all those who, accidentally or unjustly, are the victims of man-made catastrophes or natural disasters? 